\title{
Bingöl İli Rüzgar Potansiyeli ve İklim Değişikliğinin Etkisi
}

\author{
Sadık Alashan ${ }^{1, *}{ }^{*}$ \\ ${ }^{1}$ Bingöl Üniversitesi, Mühendislik Mimarlık Fakültesi, Inşaat Mühendisliği Bölümü, 12000, Bingöl. \\ Özet
}

Güneșin yeryüzünün farklı bölgelerini farklı ısıtmasından dolayı meydana gelen rüzgâr olayının, bulutların tașınarak yağmurların oluşması, çiçek tozlarının taşınarak döllenmesi, yenilenebilir ve temiz enerji kaynağı olarak kullanılma gibi birçok faydası mevcuttur. Bu çalıșmada Bingöl ili ortalama rüzgâr hızları ve günümüzde meydana gelen iklim değișikliğinin etkisi araștırılmıștır. Ayrıca çalışmada Bingöl ili üzerinde hâkim olan rüzgâr yönü ve esen rüzgârın hangi yönden ne kadar sürekli olduğu araștırılmıștır. Rüzgâr hızı potansiyeli belirleme çalışmaları literatürde çok fazla yer almasına karşın bu potansiyelin iklim değişikliği ve/veya şehirleşme karşısında davranışını belirleme çalışmaları güncelliğini korumaktadır. Bu çalışma iki aşamada gerçekleşmekte olup birinci aşamada rüzgar hızı potansiyeli belirlenmiş, ikinci aşamada ise bu potansiyelin gelecekteki davranışı incelenmiştir. İklim değişikliği velveya şehirleşmenin etkilerini araştırmak üzere literatüre yeni kazandırılan ve birçok araştırmacı tarafindan kullanılan yenilikçi yönelim çözümlemesi (YYÇ), geleneksel doğrusal regresyon (DR) ve Mann-Kendall (MK) yöntemleri kullanılmıştır. Yapılan çalışmalar sonucunda Bingöl ilinin genel olarak kuzeybatı yönünden rüzgârlarla beslendiği ve rüzgâr potansiyelinin tüm aylarda azalma eğiliminde olduğu ve söz konusu üç yönteminde birbirleri ile tutarl sonuçlar verdiği tespit edilmiştir.

Anahtar Sözcükler

İklim Değişikliği, Yönelim, Şen Yenilikçi Yönelim Analizi, Rüzgâr, Bingöl

\section{Wind Potential of Bingöl Province and the Impact of Climate Change}

\begin{abstract}
The winds are comprised of different heating of different areas by sun are beneficial to move clouds for precipitation and to transport pollen for fertilize of plants and used to generate clean and renewable energy resource. In this study, wind velocity and its change against the climate change is investigated for Bingöl province, Turkey. Furthermore, the continuity of the wind potential according to geographical directions for this city is investigated and the prevailing wind direction is determined. Although there are many studies on wind potential calculation, the determination of climate change and/or urbanization effects on this resource is new and current in the literature. In this study, firstly wind potential in Bingöl province is calculated and then the future behavior of this resource is examined. Innovative trend analysis which is a new trend determination method and used many researchers as well as traditional linear regression and Mann-Kendall methods are used to investigate the climate change and urbanization effects on winds in the city. As a result, northwest winds are prevailed on the city and the wind potential has a decreasing trend and all three methods give consistent results relative to each other.
\end{abstract}

$\underline{\text { Keywords }}$

Climate Change, Trend, Şen Innovative Trend Analysis, Wind, Bingöl

\section{Giriş}

İnsanoğlu çok eski zamanlardan beri rüzgâr gücünü, tahılları öğütmek amacıyla değirmenlerde, suyun daha yüksek seviyelere taşınması için su kaynaklarında ve ticaret için yelkenlilerle deniz yolculuklarında kullanmışlardır. Günümüzde teknolojinin gelişmesi ile birlikte elektrik enerjisi üretmek amacıyla da kullanılmaktadır. İklim değişikliğinin insan kaynaklı ana nedenlerinden olan fosil yakıt tüketimi (tükenebilir ve kirletici) atmosferdeki sera gazlarının sürekli artmasına neden olmaktadır. Rüzgâr gücü yenilenebilir ve temiz enerji kaynaklarından olduğundan enerjisini güneşten alarak tükenebilir ve kirletici kaynaklara olan bağımlılığın azalmasına imkân tanımaktadır. İlk kurulum maliyeti yüksek olmasına rağmen teknolojiyle birlikte bu maliyet de giderek düşmektedir. Hammadde tüketimi gerektirmez ve bu durum ülke dışına döviz çıkışını sınırlar ve dış ticaret açığını azaltır. Rüzgâr hızına bağlı olarak güç hesaplanması ile alakalı yerli literatürde birçok çalışma mevcuttur (Pusat 2017; Koyuncu ve Lüle 2009; Aydın 2014; Mert ve Karakuş 2015; Kaplan 2016; Emeksiz vd. 2016; Dinçer vd. 2017; Akpınar ve Balpetek 2019). Geçmiş dönemlerde çok fazla kullanılan fosil yakıtlar atmosfere aşırı derecede sera gazı salınımı yaparak iklim değişikliğini günümüzde hissedilir duruma getirmiştir. Güneşin yeryüzünü farklı miktarlarda 1sıtması ve yeryüzünün güneş 1şınımını farklı derecelerde yansıtması ve dünyanın kendi ekseni etrafında dönmesi sonucu meydana gelen rüzgârlar iklim değişikliğinden zorunlu olarak etkilenmektedir. 
Hava sıcaklıklarının artması (azalması) ile hava basıncında azalış (artış) meydana gelmektedir. Hava kütlelerinde meydana gelen basınç artışı veya azalışı yatay hava hareketleri (rüzgarlar) ile dengelenmektedir. İklim değişikliği hava sıcaklıklarında ve dolayısıyla hava kütlelerinde basınç değişimine neden olarak rüzgârlarda artma veya azalma yönelimi meydana getirmektedir. Kuzey yarımkürede orta kuşakta meridyenler arası sıcaklık farkları ve dolayısıyla basınç farkları azaldığından rüzgârlarda azalma beklenmektedir (Karnauskas vd. 2018). Bunun dışında nüfusun artışı ile birlikte hızla büyüyen şehirleşmenin ürünü yapılar da rüzgârları engellemektedir. Meteorolojik değişkenler üzerinde meydana gelen yönelim (trend) etkisini belirlemek üzere Mann-Kendall, sıralı Mann-Kendall, Spearman rho, doğrusal regresyon (lineer regresyon) çözümlemesi gibi çok kullanılan geleneksel yönelim belirleme yöntemleri yanında son zamanlarda literatüre kazandırılan yenilikçi yönelim çözümleme yöntemi de mevcuttur (Mann 1945; Sen 1968; Kendall 1975; Şen 2012, 2017). Söz konusu yöntem birçok araştırmacı tarafından kullanılmış, görsel ve kısmi yönelim belirleme açısından diğer yöntemlere göre üstünlüğü veya diğer yöntemlerle uyumlu sonuçlar verdiği belirtilmiştir (Dabanlı vd. 2016; Öztopal ve Şen 2017; Saplıoğlu vd. 2017; Güçlü 2018; Keskin vd. 2018; Şişman 2018).

Bu çalışmanın amacı Bingöl iline ait rüzgâr hızlarını coğrafik yönlere ve esme sürekliliğine göre ay bazında belirlemek ve iklim değişikliği ve/veya şehirleşme sonucunda meydana gelen yönelimleri geleneksel doğrusal regresyon, MannKendall (MK) ve literatüre yeni katılan yenilikçi yönelim çözümleme yöntemlerini kullanarak hesaplamaktır.

\section{2. Çalışma Alanı ve Veriler}

Bingöl ili Doğu Anadolu Bölgesi’nin Yukarı Fırat bölümünde yer almaktadır. İl $41^{\circ} 20^{\prime}$ ve 39॰ 56' doğu boylamları ile $39^{\circ} 31^{\prime}$ ve $38^{\circ} 28^{\prime}$ kuzey enlemleri arasında yer almakta olup deniz seviyesinden yaklaşık 1250 metre yüksekliğe sahiptir (Şekil 1). Bu çalışmada Devlet Meteoroloji Genel Müdürlüğü'nden temin edilen 1970 ile 2017 yılları arasında 16 adet coğrafik yönde ölçülen aylık hâkim ortalama rüzgâr hızı değerleri kullanılmıştır. Rüzgâr hızına ait istatistiksel bilgiler Tablo 1'de verilmiştir. Minimum (maksimum) aylık ortalama rüzgâr hızı $1.07 \mathrm{~m} / \mathrm{s}$ (1.99 m/s) ile Ocak (Temmuz) ayında görülmektedir. Ocak ve Şubat ayları $0.39 \mathrm{~m} / \mathrm{s}$ ile minimum standart sapma değerine sahipken Temmuz ayı $0.73 \mathrm{~m} / \mathrm{s}$ ile maksimum standart sapma değerine sahiptir. Aynı zamanda Ocak ve Şubat ayları $0.2 \mathrm{~m} / \mathrm{s}$ minimum aylık rüzgar hızı değerine sahiptir. Haziran ve Ağustos ayları $3.5 \mathrm{~m} / \mathrm{s}$ maksimum aylık rüzgar hızı değerine sahiptir. Çarpıklık katsayıları $-0.32 \mathrm{~m} / \mathrm{s}$ (Temmuz) ve $0.21 \mathrm{~m} / \mathrm{s}$ (Şubat) arasında değişmektedir. Aralık ayı yüzde olarak maksimum değişim katsayısına (0.43) sahiptir.

Tablo 1: Bingöl ili aylık ortalama rüzgâr hızı istatistiksel bilgiler

\begin{tabular}{lcccccc} 
& \multicolumn{5}{c}{ Aylı ortalama rüzgâr hızı $(\mathrm{m} / \mathrm{s})$} \\
\cline { 2 - 7 } Aylar & Ortalama & $\begin{array}{c}\text { Standard } \\
\text { Sapma }\end{array}$ & Maksimum & Minimum & Çarpıklık & $\begin{array}{c}\text { Değişim } \\
(\%)\end{array}$ \\
\hline Ocak & 1,07 & 0,39 & 2,00 & 0,20 & 0,07 & 0,36 \\
Şubat & 1,12 & 0,39 & 2,00 & 0,20 & 0,21 & 0,35 \\
Mart & 1,51 & 0,47 & 2,40 & 0,40 & $-0,11$ & 0,31 \\
Nisan & 1,68 & 0,54 & 2,80 & 0,60 & $-0,07$ & 0,32 \\
Mayıs & 1,73 & 0,62 & 3,30 & 0,70 & 0,09 & 0,36 \\
Haziran & 1,97 & 0,68 & 3,50 & 0,60 & $-0,03$ & 0,35 \\
Temmuz & 1,99 & 0,73 & 3,40 & 0,50 & $-0,32$ & 0,37 \\
Ağustos & 1,85 & 0,72 & 3,50 & 0,50 & $-0,05$ & 0,39 \\
Eylül & 1,69 & 0,63 & 3,00 & 0,50 & $-0,23$ & 0,38 \\
Ekim & 1,39 & 0,55 & 2,60 & 0,50 & 0,10 & 0,40 \\
Kasım & 1,21 & 0,47 & 2,10 & 0,40 & $-0,20$ & 0,39 \\
Aralık & 1,08 & 0,46 & 2,20 & 0,30 & 0,14 & 0,43 \\
\hline
\end{tabular}




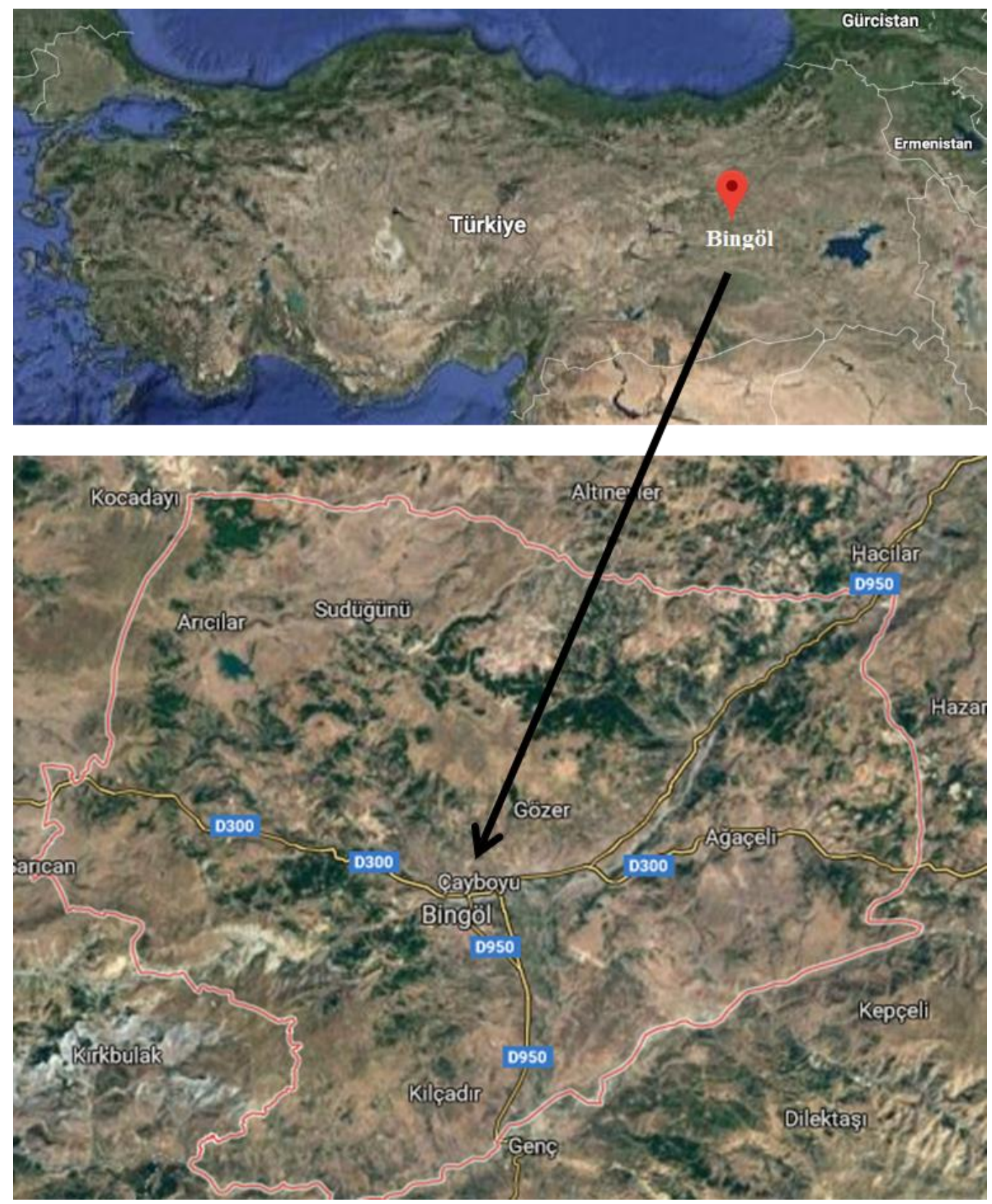

Şekil 1: Bingöl il haritası

Rüzgâr hızının şiddeti zamana ve esme yönüne göre çok fazla değişmektedir. Bingöl iline ait ortalama rüzgâr hızları esme yönüne göre Şekil 2'de verilmektedir. Bingöl ili için rüzgârın hızı yaz ve ilkbahar mevsimlerinde kış ve sonbahar mevsimlerine göre daha şiddetlidir. Rüzgârın esme yönüne göre, Ocak ayında maksimum rüzgâr hızı (m/s) güneygüneydoğu (SSE) yönünden, Şubat, Mart, Mayıs ve Haziran ayları için doğu-kuzeydoğu (ENE) yönünden, Nisan, Temmuz, Ağustos, Eylül ve Aralık ayları için kuzey-kuzeybatı (NNW) yönünden, Ekim ve Kasım ayları için güneygüneybatı (SSW) yönünden esmektedir. Mevsimsel olarak maksimum rüzgâr hızları sonbahar için kuzey-kuzeybatı ve güney-güneybat1, kış için kuzey-kuzeybatı, güney-güneydoğu ve doğu-kuzeydoğu, ilkbahar için doğu-kuzeydoğu ve kuzey-kuzeybatı, yaz için doğu-kuzeydoğu ve kuzey-kuzeybatı yönlerinden esmektedir. Ayrıca Bingöl ili için rüzgârın yönlere göre süreklilik eğrileri Şekil 3'de görülmektedir. Hâkim rüzgâr esme yönü Ocak, Şubat, Mart, Mayıs, Haziran, Temmuz, Ağustos, Eylül, Ekim, Kasım ve Aralık ayı için batı-kuzeybatı (WNW), Nisan ayı için batı (W) yönünden esmektedir. Nisan ayı için de batı (W) yönünden sonra en fazla rüzgâr batı-kuzeybatı (WNW) yönünden esmektedir. 
Ocak

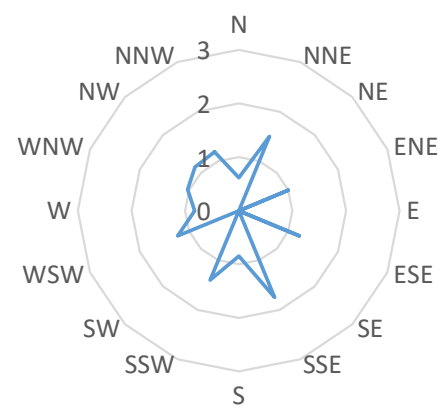

Nisan

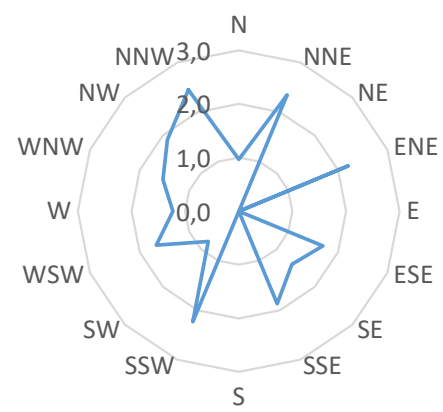

Temmuz

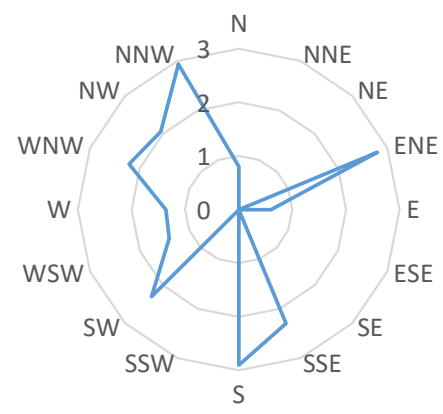

Ekim

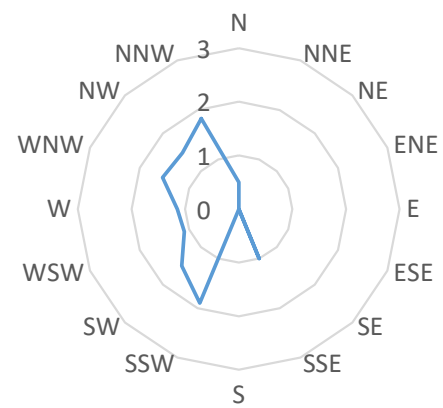

Şubat

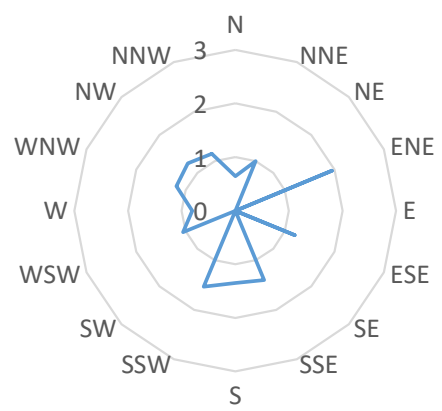

Mayıs

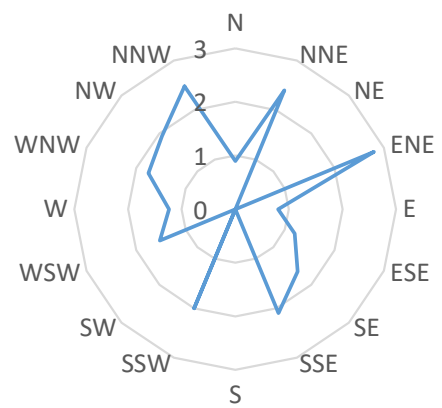

Ağustos

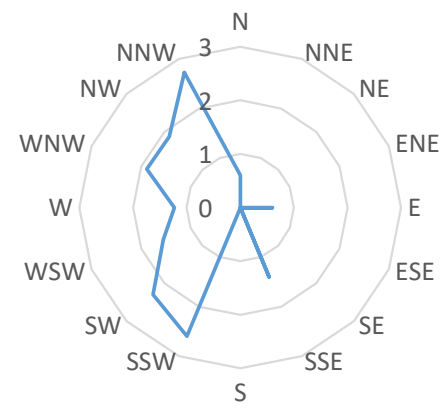

Kasım

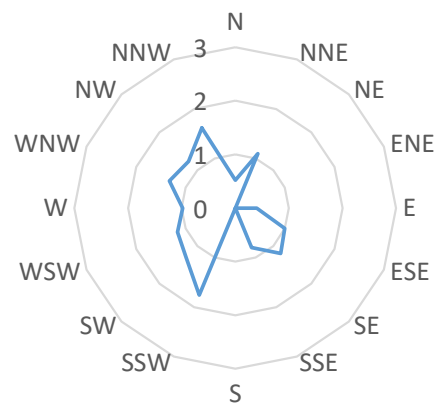

Mart

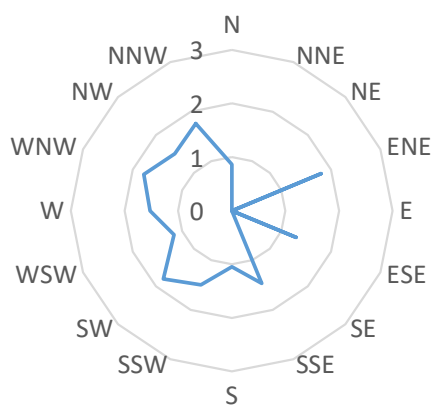

Haziran

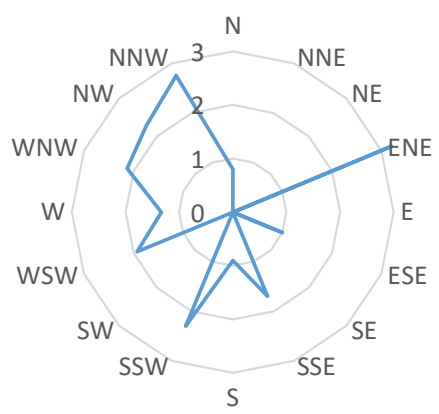

Eylül

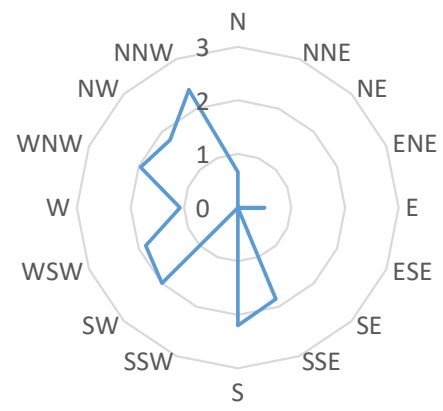

Aralık

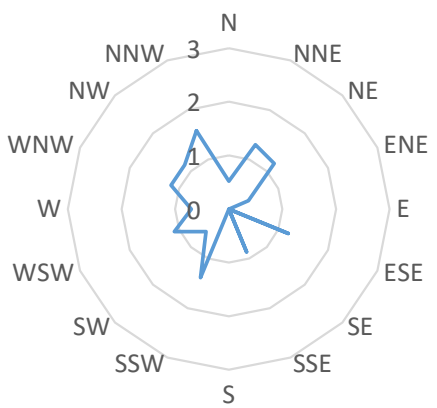

Şekil 2: Bingöl ili rüzgar yönü ve şiddeti $(\mathrm{m} / \mathrm{s})$ 
Ocak

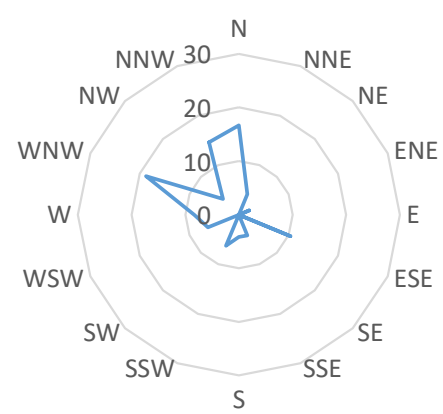

Nisan

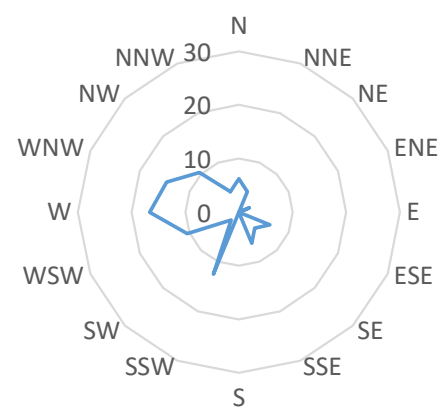

Temmuz

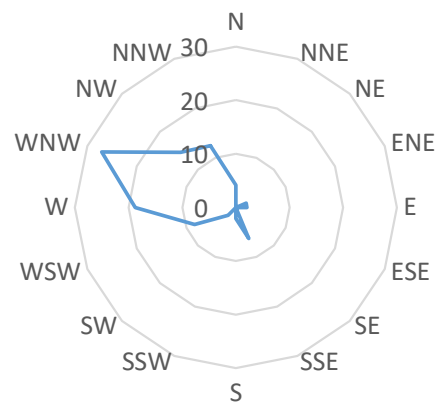

Ekim

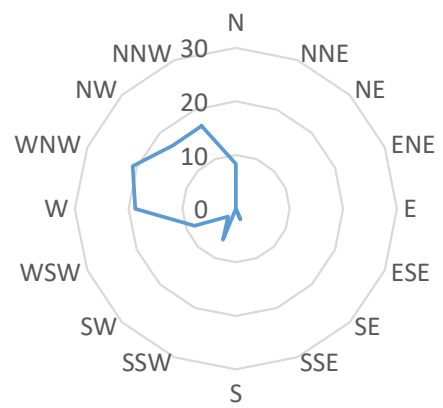

Şubat

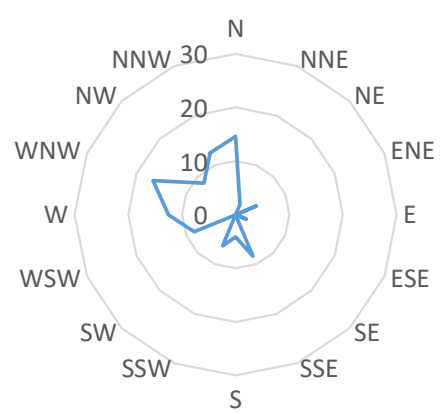

Mayıs

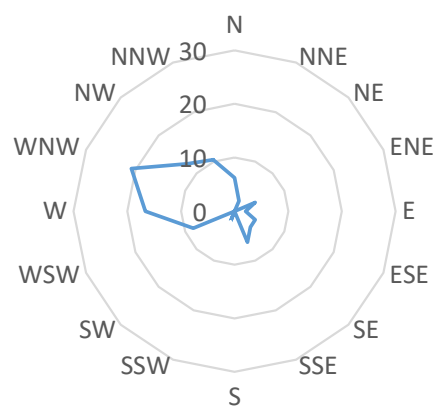

Ağustos

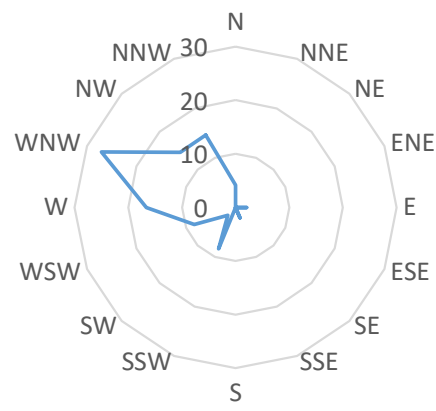

Kasım

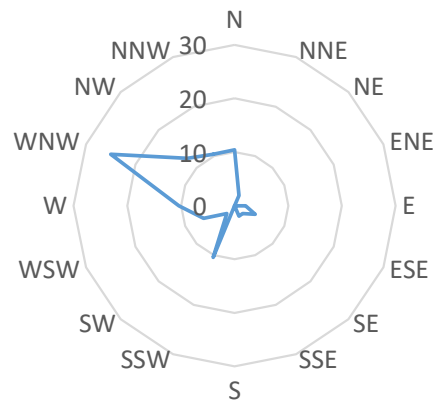

Mart

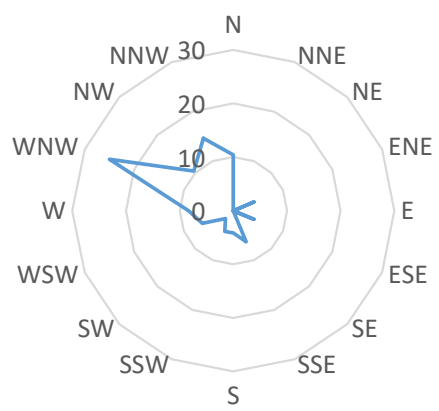

Haziran

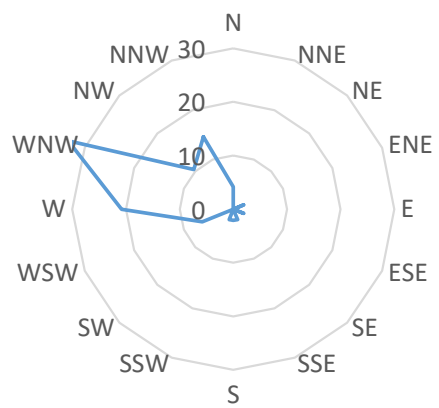

Eylül

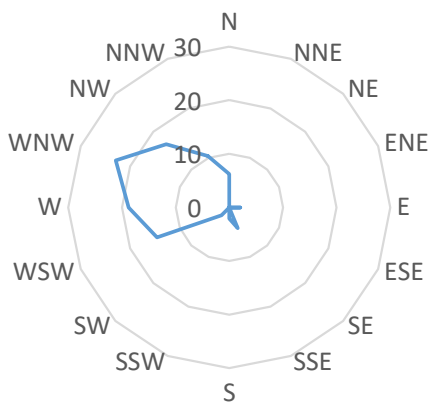

Aralık

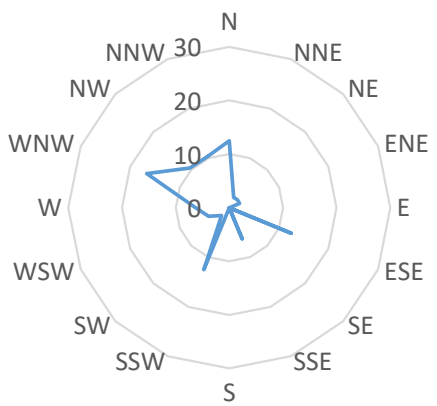

Şekil 3: Bingöl ili rüzgar frekans radar grafiği (\%) 


\section{Yöntem ve Uygulama}

Bingöl iline ait rüzgâr hızı verileri üzerindeki yönelimleri belirlemek üzere geleneksel doğrusal regresyon (lineer regresyon), Mann-Kendall (MK) ve yeni literatüre kazandırılan yenilikçi yönelim çözümleme yöntemleri kullanılmıştır. Doğrusal regresyon yöntemi zamanla değişen verilere en uygun yani toplam hatayı sıfır yapacak doğrusal eğriyi elde etmeye yarar (Denklem 1). Burada t, zaman, s, zamanla meydana gelen eğilimi, a, belli bir sabit ve $V_{r, t}$ zamana bağıml rüzgar hızını temsil etmektedir.

$$
V_{r, t}=a+s t
$$

Mann-Kendall yöntemi literatürde çok fazla kullanılan bir yönelim (trend) belirleme yöntemidir. Verilerin normal dağıldığı ve bağımsız olduğu varsayımı üzerine geliştirilmiştir. Söz konusu yöntem zamana göre sıralanan verilerin, kendi içinde belli bir istatistik önem seviyesine göre kıyaslanmasına dayanır. Eğer sıralı bir veri kendinden önce gelen bir veriden küçükse -1, büyükse 1 ve eşitse 0 değeri atanır (Denklem 2). Burada n veri sayısını göstermektedir. Bu değerler toplanarak MK test istatistiği (S parametresi) hesaplanır (Denklem 3). MK test istatistiği, S, parametresinin yayılımı (varyansı) veri sayısına ve veri içindeki bağlı gruplara (t) bağlıdır (Denklem 4). Başlangıç hipotezi (Ho) olarak veri grubu içerisinde herhangi bir yönelimin olmadığı kabul edilir. S parametresinin büyüklüğüne ve yayılımına (varyansına) bağlı olarak hesaplanan MK standart test parametresi, z, değeri kritik $\mathrm{z}_{\mathrm{k}}$ değerinden mutlak büyükse veri grubunda yönelim olduğu kabul edilir ( $\mathrm{H}_{1}$ hipotezi). Bu çalışmada kritik MK standart test parametresi, $\mathrm{z}_{\mathrm{k}}$, değeri \%99 önem seviyesi için \pm 2.58 olarak alınmıştır.

$$
\begin{aligned}
& \operatorname{sgn}\left(x_{j}-x_{i}\right)=\left\{\begin{array}{lr}
x_{i}>x_{j} & 1 \\
x_{i}=x_{j} & 0 \\
x_{i}<x_{j} & -1
\end{array}\right\} \\
& S=\sum_{i=1}^{n} \sum_{j=2}^{n-1} \operatorname{sgn}\left(x_{j}-x_{i}\right) \\
& \operatorname{Var}(S)=\frac{n(n-1)(2 n+5)-\sum t(t-1)(2 t+5)}{18} \\
& Z=\left\{\begin{array}{lr}
\frac{S-1}{\operatorname{Var}(S)} & S>0 \\
S=0 & 0 \\
\frac{S+1}{\operatorname{Var}(S)} & S<0
\end{array}\right\}
\end{aligned}
$$

Yenilikçi yönelim çözümleme (innovative trend analysis) yöntemi, esas olarak incelenecek verinin iki eşit yarım grup halinde birbiri ile kıyaslanmasına dayanır. Yöntemi uygulamak için öncelikle eldeki veri iki eşit yarım gruba ayrılır. Her bir yarım gruptaki veriler kendi arasında küçükten büyüğe doğru sıralanır. Sonra ilk yarım yatay eksende ve ikinci yarım düşey eksende olacak şekilde grafik üzerinde bir saçılma noktaları elde edilir. Sonra bu grafik üzerine $1: 1\left(45^{\circ}\right)$ bir düz çizgi çizilir. Söz konusu $45^{\circ}$ çizgisinin üzerindeki noktalar artma eğilimini altındaki noktalar ise azalma eğilimini gösterir. Eğer tüm saçılma noktaları 1:1 çizgisinin üzerinde (altında) ise buna tek düzenli artan (azalan) eğilim denilmektedir. Eğer saçılma noktalarının bir kısmı 1:1 (45 ) çizgisinin altında (üstünde) diğer kısmı üstünde (altında) ise buna çok düzenli artan (azalan) eğilim denilmektedir (Şekil 4). Çok düzenli eğilim durumunda veri aralığı az, orta, çok gibi kısımlara ayrılarak her bir kısım için ayrı eğilimler bulunabilir. Böylece çok düzenli eğilim grafikleri daha kolay yorumlanabilmektedir.

Rüzgar verileri zamana göre $\mathrm{V}_{1}, \mathrm{~V}_{2}, \ldots \ldots \ldots, \mathrm{V}_{\mathrm{n}}$ olarak gösterilsin. Toplam veri sayısı $\mathrm{n}$ olmak üzere ilk yarım seri (x) $\mathrm{V}_{1}, \mathrm{~V}_{2}, \ldots \ldots ., \mathrm{V}_{\mathrm{n} / 2}$ ve ikinci yarım seri $(\mathrm{y}) \mathrm{V}_{\mathrm{n} / 2+1}, \mathrm{~V}_{\mathrm{n} / 2+2}, \ldots ., \mathrm{V}_{\mathrm{n}}$ olur. Ayrıca $\bar{x}$, ilk yarım verilerinin ortalamasını ve $\bar{y}$, ikinci yarım verilerinin ortalamasını ve n toplam veri sayısı olmak üzere yönelim miktarı (s), YYÇ yöntemine göre Denklem 6 ile bulunabilir. Doğrusal regresyon ve yenilikçi yönelim çözümleme yöntemlerine ait hata oranlarını hesaplamak için yüzdesel ortalama hata oranı kullanılmıştır (Denklem 7). Burada, e yüzde cinsinden ortalama hata oranını, $\mathrm{V}_{\mathrm{h}}$ hesaplanan ve $\mathrm{V}_{\mathrm{g}}$ gözlenen rüzgâr hızlarını göstermektedir.

$$
\begin{aligned}
& s=\frac{2}{n}(\bar{y}-\bar{x}) \\
& e=\frac{1}{n} \sum_{i=1}^{n} \frac{V_{h, i}-V_{g, i}}{V_{g, i}} * 100
\end{aligned}
$$




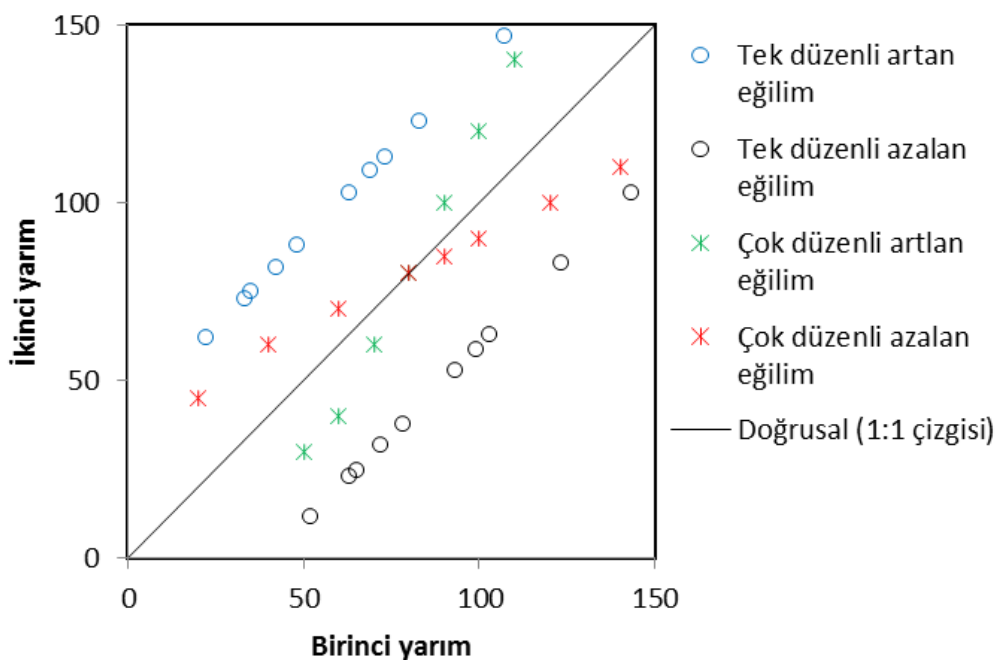

Şekil 4: Yenilikçi yönelim çözümlemesi taslak grafik

Öncelikle Mann-Kendall (MK) yöntemine göre yönelimin varlığı aylık ortalama rüzgâr hızı verileri içerisinde araştırılmıştır. MK yöntemi yönelimin büyüklüğü ile alakalı bilgi verememektedir. Bu yüzden \%99 önem seviyesine göre yönelimin yönü ve var olup olmadığı araştırılmıştır (Tablo 2). MK yöntemine göre tüm aylarda standart test parametresi, $\mathrm{z}$, değerleri -3.02 ve -5.48 aralığında bulunmuştur. $\mathrm{Bu}$ durum $(\mathrm{z}<-2.58)$ tüm aylarda \%99 önem seviyesinde azalan yönelimin olduğunu göstermektedir. DR yöntemine göre rüzgâr hızı yönelim miktarları Bingöl ili için grafiksel olarak Şekil 5 üzerinde gösterilmektedir. Bu grafiklerde mavi çizgi zamanla değişen rüzgâr hızı verilerini ve kırmızı kesikli çizgi yönelim eğrisini göstermektedir. Şekil 5 üzerinde yönelim eğrisine bakıldığında tüm aylar için azalan bir yönelim görülmektedir. Her ay için yönelim eğrisi azalan bir durum göstermesine rağmen yönelim eğrisinin eğimi dolayısıyla yönelim miktarı farklıdır. YYÇ yöntemine göre yönelim miktarları ise grafiksel olarak Şekil 6 üzerinde gösterilmektedir. Şekil üzerindeki grafiklerde yatay eksen ilk yarım seriyi, düşey eksen ikinci yarım seriyi, siyah düz çizgi $45^{\circ}$ (1:1) yönelim yok eğrisini, mavi daireler ilk yarım ve ikinci yarım sıralı seri noktalarını ve kırmızı kesikli çizgi yönelim eğrisini göstermektedir. YYÇ yöntemine göre yönelim miktarı yönelim çizgisi ile yönelim yok çizgisi arasındaki uzaklığa bağlı olarak değişmektedir. Ayrıca yönelim çizgisinin yönelim yok çizgisinin altında (üstünde) olması azalan (artan) yönelimi göstermektedir. Şekil 6 üzerinde görüldüğü üzere tüm aylarda yönelim çizgisi (kırmızı kesikli çizgi) yönelim yok çizgisinin (siyah düz çizgi) altında yani azalan yönelim miktarları vardır ve her ay için farklı miktarlardadır.

Bingöl ili rüzgâr hızı verileri üzerinde bulunan yönelimin varlığı $\mathrm{MK}$ yöntemine göre araştırılmış ve yönelim miktarları YYÇ ve DR yöntemlerine göre hesaplanmıştır. Hesaplanan yönelim miktarları ve hata oranları Tablo 2'de verilmiştir. YYÇ yöntemine göre yönelim miktarları, s, $-0.049 \mathrm{~m} / \mathrm{s} / \mathrm{y} 1 \mathrm{l}$ ile $-0.023 \mathrm{~m} / \mathrm{s} / \mathrm{y}$ ll arasında değişmektedir. DR yöntemine göre ise $-0.049 \mathrm{~m} / \mathrm{s} / \mathrm{y} 1 \mathrm{l}$ ile $-0.021 \mathrm{~m} / \mathrm{s} / \mathrm{yll}$ arasında değişmektedir. Her iki yöntem için, maksimum yönelim miktarı Ağustos ve minimum yönelim miktarı Şubat ayında meydana gelmektedir. YYÇ yöntemine göre yüzdesel ortalama hata oranları -1.20 ile -8.25 arasında değişirken DR yöntemine göre -0.14 ile -13.26 arasında değişmektedir. YYÇ yönteminde hata oranları tüm aylarda \%10 ‘dan az hesaplanmıştır.

Tablo 2: Bingöl ili aylık ortalama rüzgâr hızı verileri yönelim ve hata miktarları

Aylar Ocak Şubat Mart Nisan Mayıs Haziran Temmuz Ağustos Eylül Ekim Kasım Aralık

\begin{tabular}{|c|c|c|c|c|c|c|c|c|c|c|c|c|c|c|}
\hline \multirow{5}{*}{$\begin{array}{c}\text { Yönelim } \\
\text { parametreleri }\end{array}$} & IK & Z & -3.02 & -3.03 & -3.13 & -4.64 & -5.02 & -4.72 & -4.62 & -5.48 & -5.13 & -4.69 & -4.25 & -4.04 \\
\hline & \multirow{2}{*}{ YYÇ } & s & -0.023 & -0.023 & -0.024 & -0.033 & -0.041 & -0.042 & -0.046 & -0.049 & -0.040 & -0.035 & -0.026 & -0.02 \\
\hline & & $\mathrm{a}$ & 1.63 & 1.67 & 2.09 & 2.48 & 2.70 & 2.99 & 3.11 & 3.03 & 2.66 & 2.23 & 1.84 & 1.84 \\
\hline & \multirow{2}{*}{ DR } & $\mathrm{s}$ & 0.022 & -0.021 & -0.025 & -0.033 & -0.040 & -0.044 & -0.047 & -0.049 & -0.041 & -0.036 & -0.028 & -0.028 \\
\hline & & $\mathrm{a}$ & 4.77 & 43.42 & 51.84 & 68.33 & 82.25 & 90.20 & 95.14 & 98.97 & 83.19 & 72.80 & 57.30 & 57.30 \\
\hline \multirow{2}{*}{$\begin{array}{c}\text { Ortalama yüzde } \\
\text { hata (e ) \% }\end{array}$} & \multicolumn{2}{|c|}{ YYÇ } & -7.53 & -8.25 & -6.84 & -3.38 & -2.34 & -2.86 & -5.83 & -1.20 & -4.76 & -3.21 & -8.13 & -8.13 \\
\hline & \multicolumn{2}{|c|}{ DR } & -12.19 & -11.51 & -12.25 & -6.90 & -0.14 & 4.15 & -7.58 & -2.38 & -1.09 & -4.99 & -13.26 & -13.26 \\
\hline
\end{tabular}



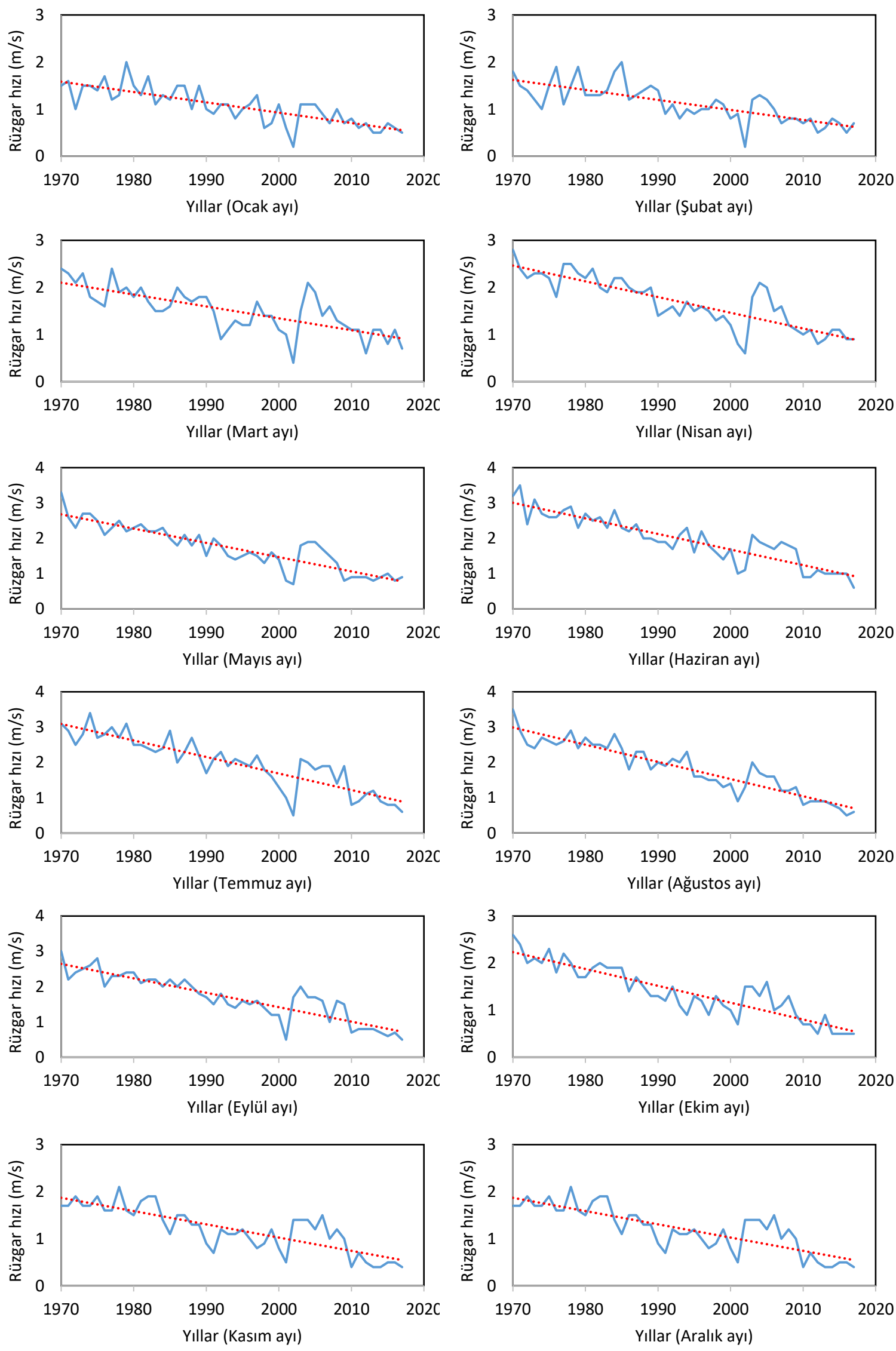

Şekil 5: Doğrusal regresyon analiz sonuçları 

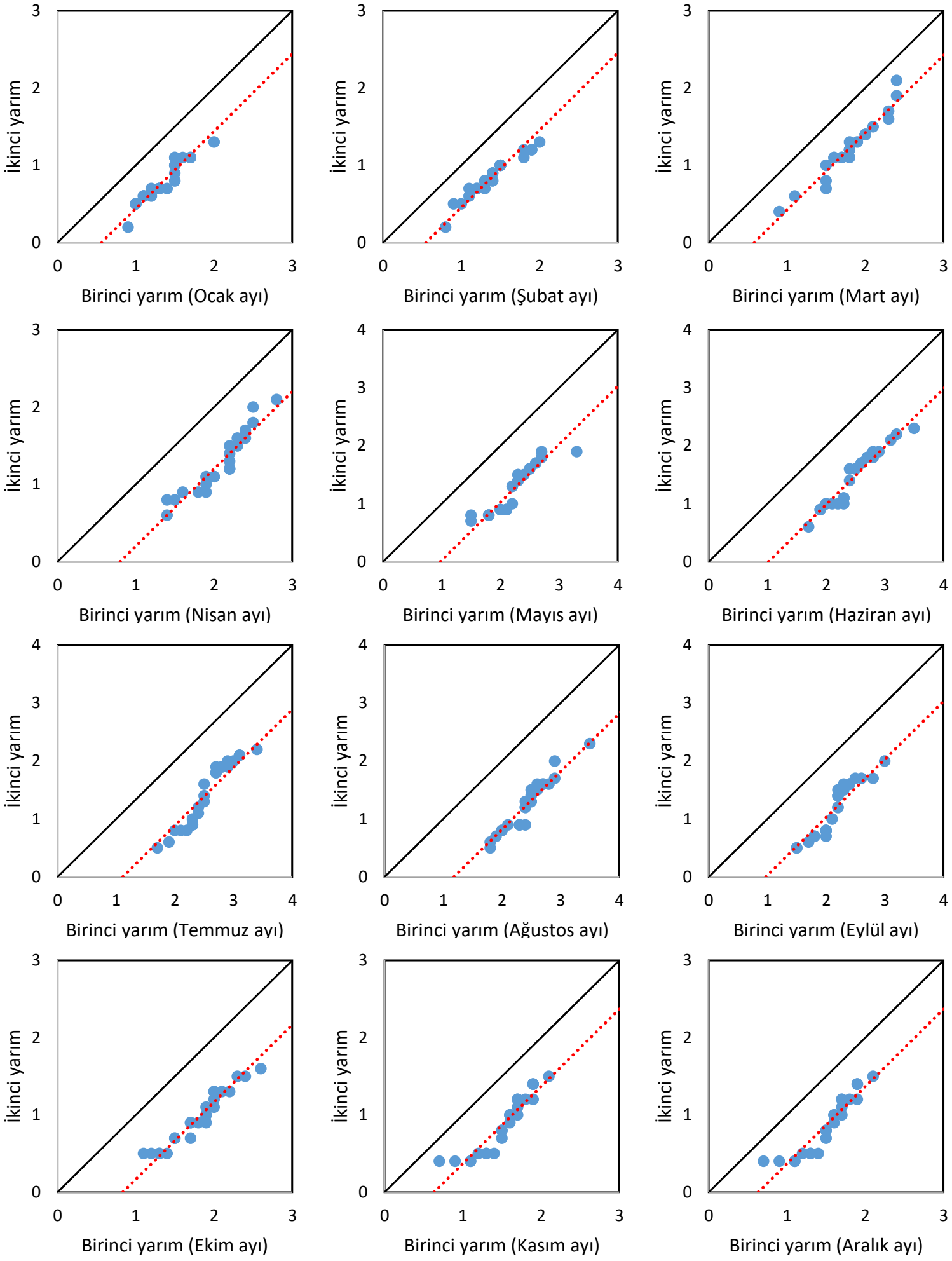

Şekil 6: Bingöl İli aylık ortalama rüzgâr hızları $(\mathrm{m} / \mathrm{s})$ lç̧in yenilikçi yönelim analiz sonuçları 

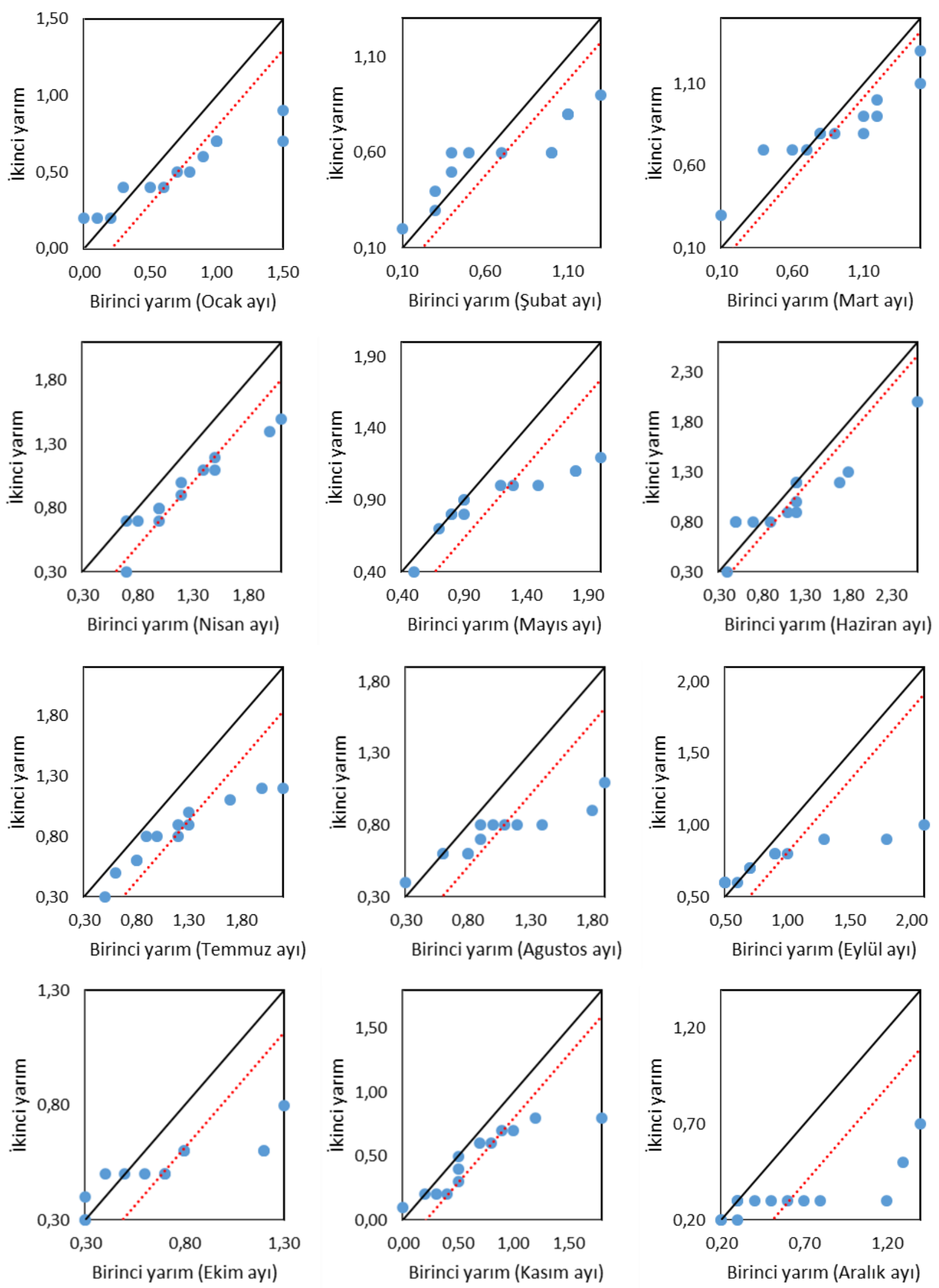

Şekil 7: Genç ilçesi aylık ortalama rüzgâr hızları $(\mathrm{m} / \mathrm{s})$ için yenilikçi yönelim analiz sonuçları 
Küresel iklim faktörlerinin Bingöl ili aylık ortalama rüzgâr verilerinin azalma eğilimi üzerinde etkisini irdelemek üzere kırsal bölge analizi ve genel iklim modeli değerlendirmelerinden faydalanılmıştır. İklim parametrelerindeki değişikliğin küresel ölçekli faktörlerden mi yoksa yerel faktörlerden mi kaynakladığını belirlemek için şehrin meteoroloji istasyonu yanında kırsal alandaki istasyonları analiz etmek gerekmektedir (Gönençgil 2011; Kum ve Kılıç 2013). Kırsal bölge değerlendirmesi için 2018 yılına ait şehir nüfusu 117556 kişi olan Bingöl iline yaklaşık 16 km uzaklıkta bulunan ve aynı yıl için 16565 nüfusa sahip Genç ilçesine ait aylık ortalama rüzgâr verilerinin YYÇ yöntemine göre analizi yapılmıştır (Şekil 7). Söz konusu analizde Genç ilçesi için de tüm aylarda azalma eğilimi elde edilmiştir.

Genel iklim modelleri değerlendirmelerinde istisnai durumlar hariç, Karnauskas vd. (2018) tarafından kuzey yarımkürede orta kuşakta (Türkiye) rüzgâr olaylarının azalması beklenmektedir. Vautard vd. (2010) tarafından 822 meteoroloji istasyonunun 1979-2008 yılları arasındaki ölçülen rüzgâr verilerini kullanarak yapılan çalışmada, kuzey yarımkürede orta kuşakta \%5 ile \%15 arasında rüzgâr hızlarının azaldığı ve güçlü rüzgârların zayıf rüzgârlardan daha fazla yavaşladı̆̆ı belirtilmiştir.

\section{Sonuçlar}

Bingöl ili rüzgâr hızı potansiyeli incelenen istasyon için aylara göre ortalama $1.07 \mathrm{~m} / \mathrm{s} \mathrm{ve} 1.99 \mathrm{~m} / \mathrm{s}$ arasında değişmektedir. Söz konusu rüzgâr hızı verileri esme yönüne göre çok fazla değişmekte olup, şehir esas olarak kuzeybatı rüzgârlarıyla beslenmektedir. Bingöl ili ortalama rüzgâr hızı verileri üzerinde tek düzenli azalan bir yönelim vardır. Yönelim miktarları aylara göre $-0.049 \mathrm{~m} / \mathrm{s} / \mathrm{y} 1 \mathrm{l}$ ile $-0.023 \mathrm{~m} / \mathrm{s} / \mathrm{y} 1 \mathrm{l}$ arasında değişmektedir. Analizde kullanılan rüzgâr hızı verilerinde 1970 2017 yılları arasında (38 yıl) dönemsel olarak $0.87 \mathrm{~m} / \mathrm{s}$ ile $1.86 \mathrm{~m} / \mathrm{s}$ arasında azalma meydana gelmiştir. Yönelim miktarları geleneksel doğrusal regresyon (DR) ve yenilikçi yönelim çözümlemesi (YYÇ) yöntemleri ile hesaplanmıştır. Üç farklı yöntemin sonuçlarının birbiriyle tutarlı olması elde edilen sonuçların güvenirliğini artırmaktadır. YYÇ yöntemi ile hesaplanan değerler mühendislik çalışmalarında kabul edilebilen \%10 hata sınırının (Şen 2002) altındadır ve DR yöntemine göre daha iyi sonuç vermiştir. YYÇ yönteminin diğer iki yöntemle tutarlı sonuç vermesi yöntemin güvenirliğini, DR yöntemine göre daha az hata oranı vermesi ise yöntemin hassasiyetini göstermektedir. Bingöl ili aylık rüzgâr hızı verileri üzerinde bulunan azalan yönelimlerin şehirleşmeyle birlikte iklim değişikliğinden kaynaklandığ1 düşünülmektedir. Kırsal alan değerlendirmesi (Genç ilçesi) ve genel iklim değerlendirmeleri bu sonucu destekleyici niteliktedir. Şehirlerde rüzgâr olayları üzerindeki azalma eğiliminde şehirleşmenin etkisi (1S1 adası, rüzgâr bariyerleri) inkâr edilemese de bulgular rüzgâr verilerinde meydana gelen azalma eğilimlerinde şehirleşmeye ilave olarak küresel iklim faktörlerinin de rol aldığını düşündürmektedir. Bu durumun mühendislik, ziraat ve çevre planlamalarında doğru kararlar alınması için göz önünde bulundurulması gerekmektedir. Özellikle mevcut rüzgar potansiyeline göre Türkiye'de kurulan rüzgar santrallerinde gelecekte yeterli enerji üretememe gibi sorunlarla karşılaşılması olasıdır.

\section{Kaynaklar}

Akpınar E.K., Balpetek N., (2019), Weibull ve Rayleigh dağılımlarına göre Elazı̆̆ ilinin rüzgâr enerjisi potansiyelinin istatiksel analizi, Gazi Üniversitesi Mühendislik-Mimarlık Fakültesi Dergisi, 34(1), 569-580.

Aydın İ., (2014), Balıkesir'de rüzgâr enerjisi, Doğu Coğrafya Dergisi, 18(29), 29-50.

Dabanlı İ., Şen Z., Yeleğen M.Ö., Şişman E., Selek B., Güçlü Y.S., (2016), Trend assessment by the innovative-şen method, Water Resources Management, 30, 5193-5203.

Dinçer F., Rüstemli S., Yılmaz Ş., Çıngı A., (2017), Kilis ili için farklı yüksekliklerdeki rüzgâr potansiyelinin belirlenmesi, Bitlis Eren Üniversitesi Fen Bilimleri Dergisi, 6(1), 12-20.

Emeksiz C., Doğan Z., Gökrem L., Yavuz A.H., (2016), Tokat bölgesi rüzgar karakteristiğinin istatistiksel yöntemler ile incelenmesi, Politeknik Dergisi, 19(4), 481-489.

Gönençgil B., (2011), Şehirleşmenin sıcaklık trendleri üzerine etkileri ve şehirsel ısı adası kavramı, Fiziki Coğrafya Araştırmaları, Sistematik ve Bölgesel, Prof. Dr. M. Yıldız Hoşgören Anısına Armağan içinde (Ekinci, D., Ed.), Türk Coğrafya Kurumu , İstanbul, ss.127-136.

Güçlü Y.S., (2018), Klyaslamalı yenilikçi eğilim çözümlemesi temelleri ve uygulamaları, Doğal Afetler ve Çevre Dergisi, 4(2), 182191.

Kaplan Y.A., (2016), Rayleigh ve Weibull dağllımları kullanılarak osmaniye bölgesinde rüzgar enerjisinin değerlendirilmesi, Süleyman Demirel Üniversitesi Fen Bilimleri Enstitüsü Dergisi, 20(1), 62-71.

Karnauskas K.B., Lundquist J.K., Zhang L., (2018), Southward shift of the global wind energy resource under high carbon dioxide emissions, Nature Geoscience, 11, 38-43.

Kendall M.G., (1975), Rank correlation methods, Charles Griffin, London, 202ss.

Keskin A.Ü., Beden N., Demir V., (2018), Analysis of annual, seasonal and monthly trends of climatic data: a case study of Samsun, Nature Sciences (NWSANS), 13(3), 51-70.

Koyuncu T., Lüle F., (2009), Ondokuz Mayls Üniversitesi Kurupelit Kampüsünün rüzgar enerjisi potansiyelinin belirlenmesi, Tekirdağ Ziraat Fakültesi Dergisi, 6(2), 171-178.

Kum G., Kılıç S., (2013), Şehirleşmenin sıcaklık ve yă̆ış parametreleri üzerine etkisi: Gaziantep örneği, Sosyal Bilimler Dergisi, 3(6), $21-42$.

Mann H.B., (1945), Nonparametric tests against trend, Econometrica, 13(3), 245-259.

Mert İ., Karakuş C., (2015), Antakya Bölgesinde rüzgâr gücü yoğunluğu ve rüzgâr hızı dă̆ılımı parametrelerinin istatistiksel analizi, Politeknik Dergisi, 18(1), 35-42. 
Öztopal A., Şen Z., (2017), Innovative trend methodology applications to precipitation records in Turkey, Water Resource Management, 31, 727-737.

Pusat Ş., (2017), Sakarya Üniversitesi için rüzgâr enerjisi potansiyel belirleme çalışması, Pamukkale Üniversitesi Mühendislik Bilimleri Dergisi, 23(4), 352-357.

Saplığlu K., Küçükerdem T.S., Alqaysi R.S.D., (2017), Akdeniz Bölgesi akarsularının su kalitesi sinıflarının ve trendlerinin belirlenmesi, DÜMF Mühendislik Dergisi, 8(1), 33-42.

Sen P.K., (1968), Estimates of the regression coefficient based on Kendall's Tau, Journal of the American Statistical Association, 63(324), 1379-1389.

Şen Z., (2012), Innovative trend analysis methodology, Journal of Hydrologic Engineering, 17(9), 1042-1046.

Şen Z., (2017), Innovative trend significance test and applications, Theoretical and Applied Climatology, 127, 939-947.

Şen Z., (2002), İhtimaller hesabı prensipleri, Bilge Kültür Sanat, İstanbul, 128 ss.

Şişman E., (2018), Türkiye'de seçilen hava kalitesi izleme istasyonları için eğilim (trend) değerlendirmeleri, Doğal Afetler ve Çevre Dergisi, 5(1), 134-152.

Vautard R., Cattiaux J., Yiou P., Thépaut J.N., Ciais P., (2010), Northern Hemisphere atmospheric stilling partly attributed to an increase in surface roughness, Nature Geoscience, 3, 756-761. 